\title{
APPLICATION OF STRUCTURAL GEOLOGY IN THE EXPLORATION FOR RESIDUAL GEM DEPOSITS OF SRI LANKA
}

\author{
D.P.J. MENDIS, M.S. RUPASINGHE and C.B. DISSANAYAKE
}

\begin{abstract}
D.P.J. MENDIS, M.S. RUPASINGHE and C.B. DISSANAYAKE 1993.
Application of structural geology in exploration for residual gem deposits of Sri Lanka. Bull. Geol. Soc. Finland 65, Part 1, 31-40.

Geological investigations of some major gem-bearing areas of Sri Lanka have shown that the gem deposits are controlled by the geological structure. Corundum deposits are generally associated with axial plane areas of tight, doubly plunging synclinoria and anticlinoria where occurrences of crystalline limestones and pegmatites are observed. Corundum deposits also occur at sites of heavy structural disturbances such as discontinuities, faults, folds, joints, lensing and necking zones etc. if occurrences of marbles and/or intrusions of granite and pegmatites have taken place. Alluvial gem deposits do not necessarily exist close to the area where they originate, but most concentrations of alluvial gem beds still remain close to the source area.

Detailed investigations of the geological structure of a gem-bearing area and the relationship of these structural elements with appropriate source rocks will yield vital clues to the existence of gen deposits.
\end{abstract}

Key words: Gem minerals, geological structure, gem exploration, Sri Lanka.

\section{D.P.J. Mendis, M.S. Rupasinghe and C.B. Dissanayake, Institute of Fundamental} Studies, Hantana Road, Kandy Sri Lanka.

\section{INTRODUCTION}

Sri Lanka is well known for its wide variety of gemstones. These minerals are found in modern alluvial deposits.

The streams in alluvial systems are structurally controlled and follow the structural patterns and the relative erodibility of the underlying geological formations. All gem deposits of Sri Lanka are located in the Central Highland Complex (Fig. 1) mostly consisting of granulite facies rocks. The gems occur mainly in alluvial gravels occupying the wide strike valleys into which tributary hillside streams flow, apparently carrying gemstones released from the hilltop or hillside bedrock sources during weathering. The gem-bearing gravel (illam) commonly lies at the base of the alluvium at or near the bedrock surface generally $1 \mathrm{~m}$ to $10 \mathrm{~m}$, but occasionally as much as $30 \mathrm{~m}$ beneath the ground surface. The mining of these deposits involves sinking pits or shafts through the alluvium and tunnelling to follow the pay gravels. The pay gravel, however, does not form a continuous sheet and rich patches may change abruptly to barren intervals, and appear to occupy palaeochannels in the alluvium.

The discovery of new gem-bearing gravels in Sri Lanka is still based on 'hear-say' methods. The systematic study of their spatial distribution, their bed rock sources, geological and geochemical methods of readily identifying areas with high potential for gems has commenced only recently 


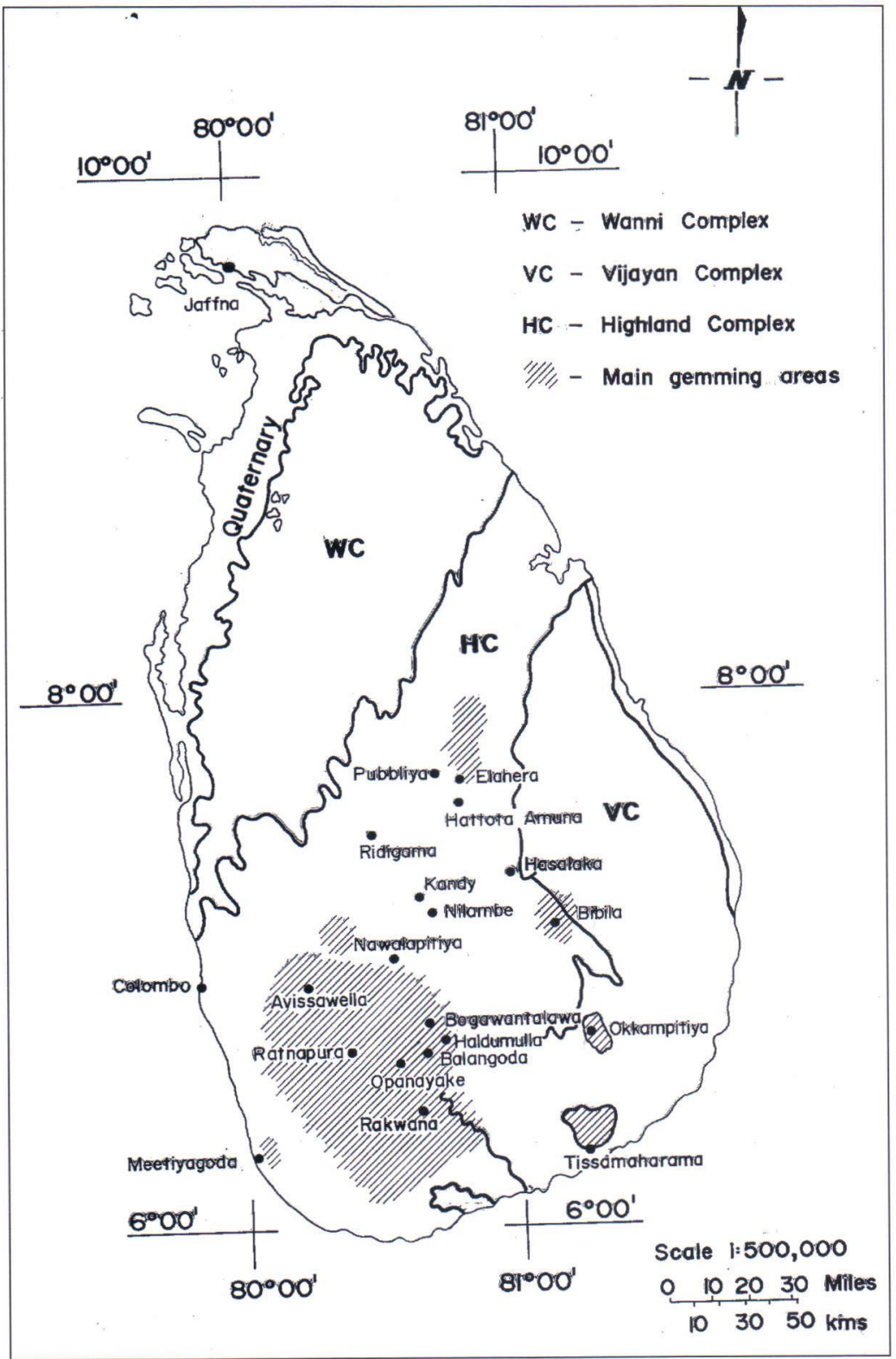

Fig. 1. Simplified geological map and location of gem deposits of Sri Lanka.
Sri Lanka.

\section{THE GEM-BEARING TERRAINS OF SRI LANRA}

Ninety percent of Sri Lanka is underlain by Precambrian metamorphic rocks. These rocks form three major divisions, namely the Wanni Complex, Highland/Southwestern Complex, and Vijayan Complex (Kroner et al. 1991, Kriegsman 1991).

The rocks of the Highland/Southwestern Complex mainly consist of a suite of metasedimentary and possibly metavolcanic rocks formed under granulite facies conditions. The prominentrock types among Highland/Southwestern Complex are charnockites (acid, intermediate and basic), undifferentiated metasediments (garnetiferous granulites, garnetiferous biotite gneiss, garnet sillimanite-biotite gneiss), khondalites (quartz-feldspar-garnet and sillimanitegraphite schists), quartzites, crystalline limestones, calcgneiss and granulites and amphibolites. The rocks are
(Mendis et al.1991, Dissanayake et al. 1992, Gamage et al. 1992). It is the aim of this paper to illustrate the use of structural geology as a tool in the exploration for alluvial gem deposits. This work forms a part of a larger study on the application of modern scientific techniques to gem exploration in found closely associated with one another in an interbedded relationship. The charnockites are the prominent group of rocks in the Highland Complex and the key observation is that most of the gem deposits of Sri Lanka are confined to the Highland Complex, particularly to the Southwestern part of 
it. The latter consists mainly of calciphyres, charnockites and cordierite-bearing gneisses.

The largest gem fields in Sri Lanka are located in the Sabaragamuwa Province in the Southwest in the areas around Avissawella, Balangoda, Rakwana, and Ratnapura. Several gem fields also lie around Elahera, Okkampitiya and Hasalaka (Fig. 1). The sedimentary gem-bearing beds are classified into three types : 1. residual 2. eluvial and 3. alluvial (Dahanayake et. al. 1980). The residual beds bear gem minerals mostly deposited in situ, whereas eluvial beds have minerals transported along slopes of ridges and deposited away from the parent rock. The alluvial beds, on the other hand contain gem minerals transported along streams and deposited at a greater distance from the parent rock.

\section{STUDY AREAS}

Areas representing three different levels of gem potential were selected as follows (Fig. 1):

1. High potential: areas of extensive current gem production. Opanayake (Fig. 2) and Hattota Amuna (Fig. 4). Both are underlain by rocks of the Highland/Southwestern Complex.

2. Moderate potential: areas where some gems have been discovered but from which there has been little or no production. Bogawantalawa (Fig. 3), Pubbiliya (Fig. 4) - these areas are also underlain by rocks of the Highland/Southwestern Complex.

3. Low, very low or no potential: areas with no (orinsignificant) discoveries and/or unfavourable geology (eg. Vijayan Complex). Nilambe (Fig. 5), Kurunegala-Ridigama, Wariaypola (Fig. 6).

\section{LEVEL 1}

\section{Opanayake}

Fig. 2 illustrates the location of the gem deposits in relation to the geological structure of the area. The general structure consists of a large synclinorium

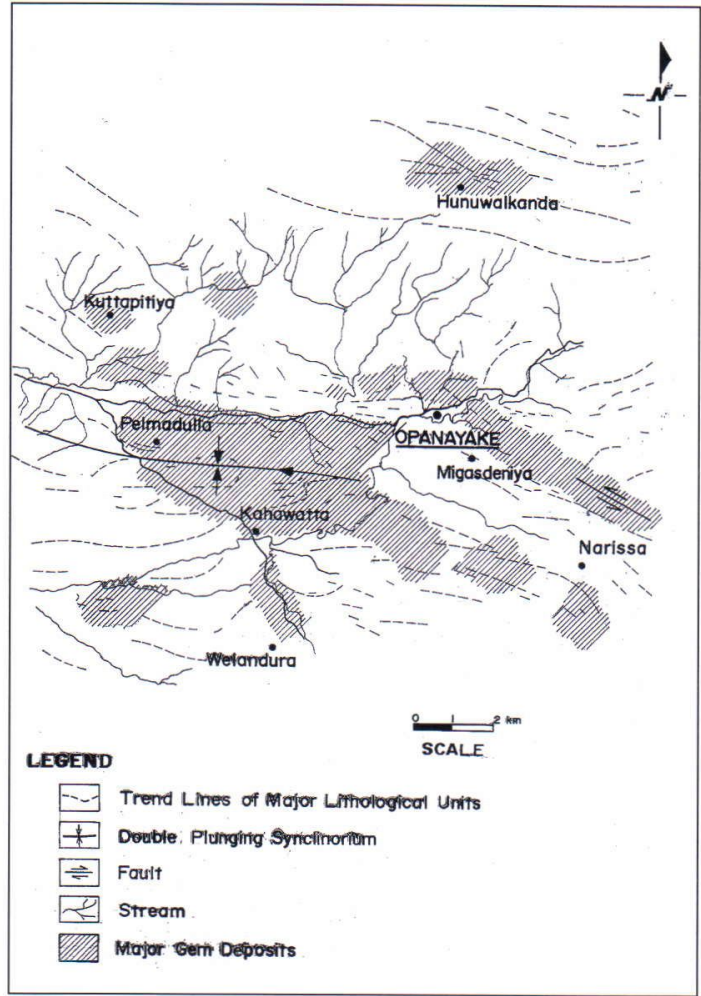

Fig. 2. Location of the gem deposits in relation to the geological structure of Opanayake area.

with the axis trending generally west-east through Pelmadulla and Kahawatta. The trend lines and the crestal zone are heavily tectonized and are disturbed to an extent that makes it difficult to interpret on aerial photographs due to subsidiary folding and faulting. Intense weathering creates further problems in deciphering the structural features. Large necking zones can be seen at Hunuwalkanda in the north of the working area and a NW-SE fault zone (more than $5 \mathrm{~km}$ in strike length) occurs on the eastern side of Opanayake.

Unlike the other areas studied, all these said major folds and necking zones are characterized by intrusive marble and pegmatites and also a high abundance of gems was noted. Some of the gems found in the area are: sapphire, spinel, tourmaline, zircon and garnet.

The Pelmadulla Opanayake-Kahawatta triangle is the most tectonically disturbed area and also the 


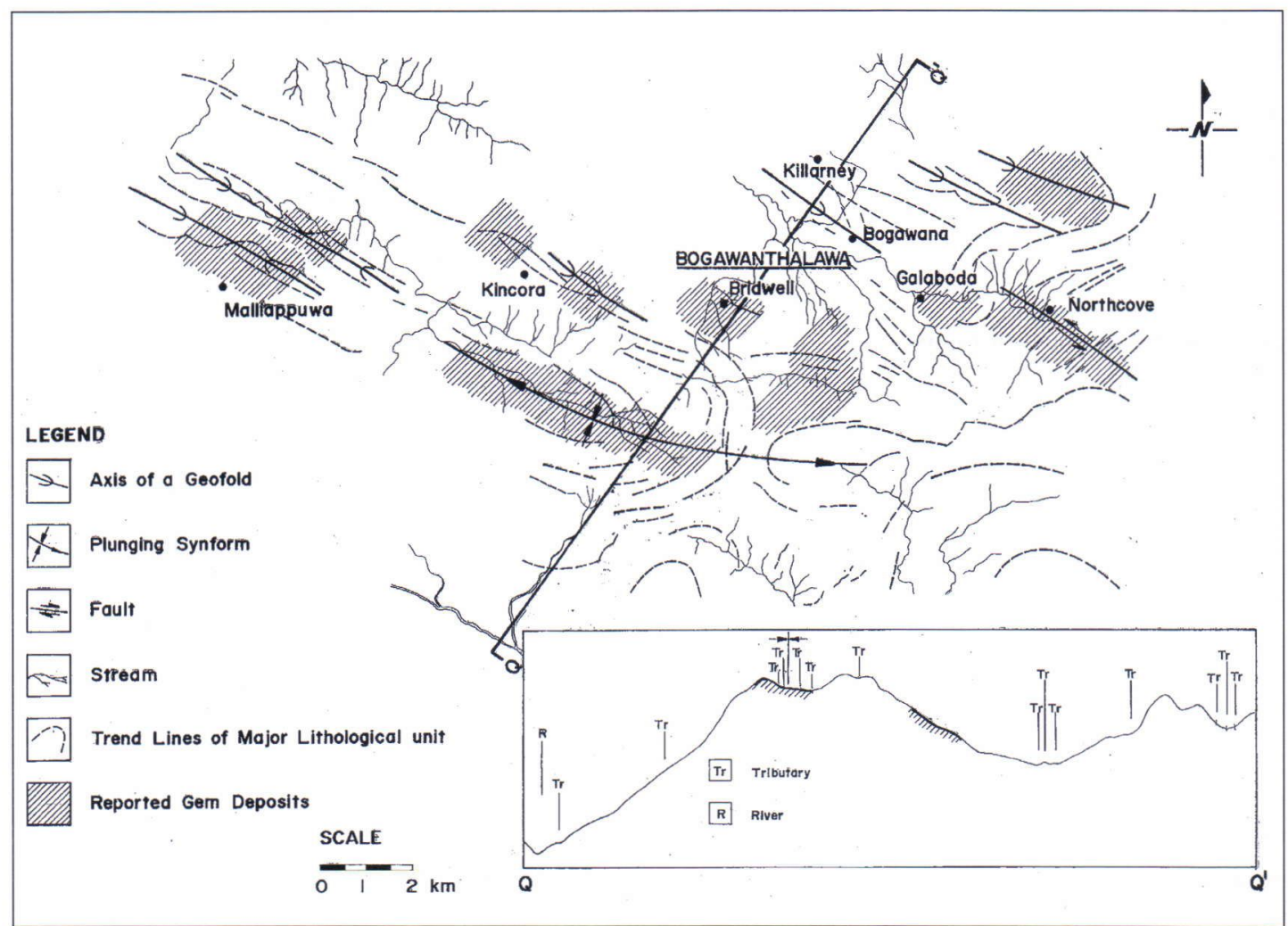

Fig. 3. Location of gem deposits in relation to the geological structure of Bogawantalawa area.

place where there is the most obvious connection between gems and structure.

\section{Hattota Amuna}

The Hattota Amuna gemming area is associated with a large megascale synclinorium structure with its N-S trending axial plane through Bakmuna Hattota Amuna (Fig. 4). This synclinorium has a wavelength of more than $10 \mathrm{~km}$ and its axial plane can be followed about $35 \mathrm{~km}$. The Pallegama parasitic synform occurs to the south of Hattota Amuna along the same axial plane. Another parasitic, elongate synform was noted in the west of the major synclinorium at Hattota Amuna.

The area also contains lineaments of NW-SE and NE-SW trend, some of which are faults. The major drainage of the area, the Kalu Ganga river (N-S), is controlled by the fold axis of the major synclinorium for a short distance at Hattota Amuna and then by the limbs of the synclinorium. The tributaries to the Kalu Ganga river follow the lineaments and carry the sediments into the major stream across the axial plane at its west, across the limbs in the east.

The existing gem mining in the region seems to be confined to the following areas:

1. Areas along the axial plane of the Bakamuna Hattota Amuna synclinorium, where there are in-situ and residual deposits. Gem varieties found here are: sapphire, tourmaline, zircon, spinel and garnet.

2. Areas along the Kalu Ganga river and flanks which are underlain by alluvial sediments. The gem varieties found here are the same as those found along the axial plane of the Bakamuna Hattota Amuna synclinorium. 


\section{LEVEL 2}

\section{Bogawantalawa}

This area is thrown into a series of NW-SE trending synforms and antiforms (Fig. 3). The north cave fault zone is parallel to the same direction and prominent ridges and valleys follow the trend lines for many kilometres. Valuable gems such as star sapphires, tourmaline, spinel and garnet have been found in the area. The popular gemming areas are situated close to the axial planes of the major folds and within the fault zones where pegmatites and to some extent intrusive marble occur. It may be argued that the alluvial gem deposits do not necessarily exist close to the areas where they originate, but as gems usually are heavy minerals and due to the unevenness and the disturbances of the stream bed, most concentrations of alluvium gem beds still remain close to the source area.

\section{Pubbiliya}

This area consists of a closelyspaced, 10-15 km long anticlinorium and synclinorium pair (Fig. 4). In comparison with the structures in the Hattota Amuna area, these structures have the smallest wavelengths and length of the axial planes. The area north of Pubbiliya consists of a NNW-SSE fault zone which extends for more than $4 \mathrm{~km}$ and most of this area is inaccessible due to wild life. The Pubbiliya anticlinorium does not indicate mobilization of rocks showing an intrusive or retextured nature even at the axial plane areas of the area investigated. The common type of gems found here is garnet, and the occurrence of gems is in association with the axial plane.

The garnet potential of the area is as follows:

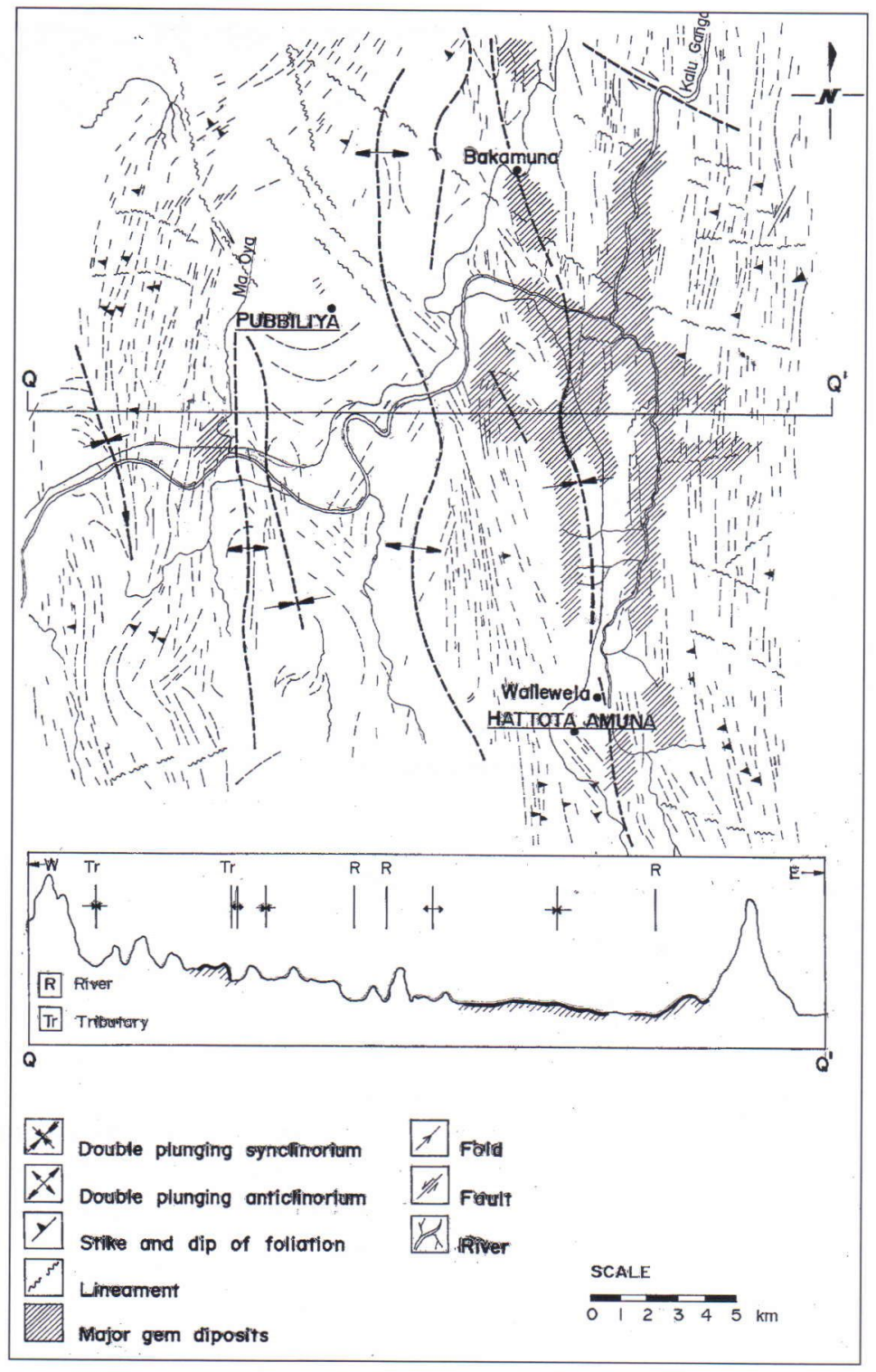

Fig. 4. Location of gem deposits in relation to the geological structure of Hattota Amuna and Pubbiliya area. 
1. Garnets occur as shallow residual deposits within garnet gneiss near the axial plane.

2. The Northern Pubbiliya fault zone is poor in alluvial beds as well as gem deposits even though gem quality garnets were found in the rocks. The Ma Oya stream begins and flows for about $4 \mathrm{~km}$ along the Pubbiliya fault zone and is then controlled by the joints and the Pubbiliya anticlinorium axis to the south. In comparison to the other streams it was observed that there are anomalously high concentrations of trace elements towards the downstream $\mathrm{N}$ to $\mathrm{S}$ area along the fault zone.

The trace element concentrations in the sediments decrease downstream as the stream deviates away from the fault zone. It can be possibly postulated that the interaction of deformation and metamorphism that occurred along the fault zone might have contributed to the high concentrations of the trace elements. This fault zone is rich in granite pegmatites, with abundant rare minerals.

\section{LEVEL 3}

\section{Nilambe}

The major stream of this area, the Nilambe Oya, more or less follows the axial plane (NW-SE) of the Nilambe synform (Fig. 5). The wavelength of this fold is about $20 \mathrm{~km}$ and the traceable length of the axial plane is more than $40 \mathrm{~km}$. In comparison to all the other areas, the Nilambe synform has the most open and the broadest structure. The synclinorium includes neither metasediment nor marble, that

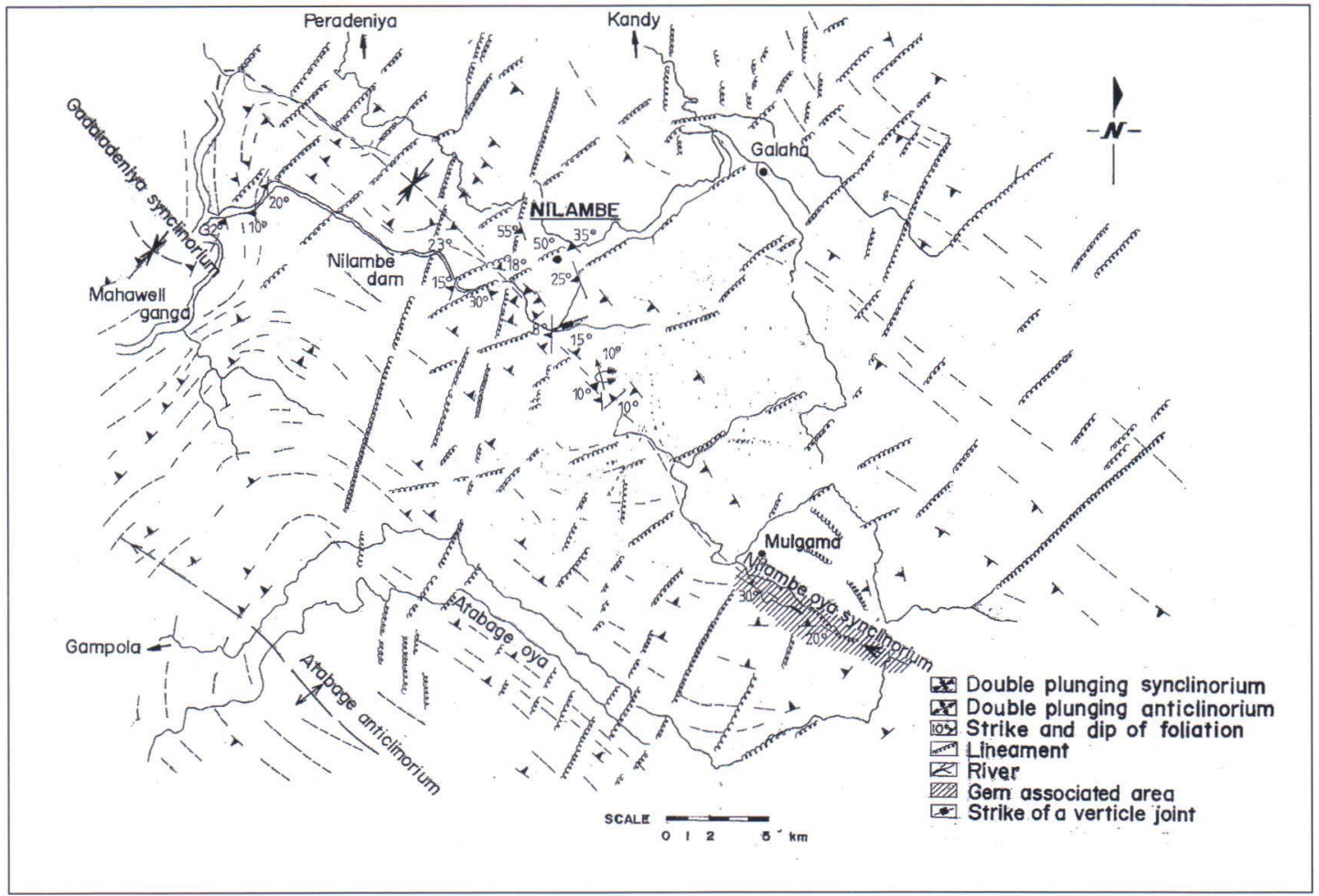

Fig. 5. Areal photographic interpretation of Nilambe area showing the geological structure and the gem associated areas. 
shows evidence of having been intruded.

Large pegmatites were not found, but small to medium localizations of pegmatites are common. Pegmatites are mainly associated with the axial plane and the crestal zones, specially towards Mulgama in the SE crestal zone. In situ or slightly residual purple or purple stained amethyst crystals without any destruction of the crystal contours are being increasingly found in the same SE crestal area. This has been noticed by the villagers who collect the crystals from the top of the soil just after the rains. An occurrence of garnets and tourmalines are also found in the same area.

\section{Ridigama}

The Ridigama sampling area lies along the boundary zone between the Wanni complex where no gems have been reported and the Highland/Southwestern Complex where gems are reported (Fig. 6). The eastern area is composed of Wanni Complex rocks whereas towards the west there is an increasing amount of Western Vijayan rocks. The area consists of rocks with tight folding into anticlinoria and synclinoria in the eastern part, but the structures become more simple towards the west.

The major lineaments in the area are NE-SW and NW-SE. The fracture pattern is more complex and some N-S, NNE-SSW major lineaments also can be noticed.

Some gem quality garnets have been reported in the eastern area, but not towards the west. The E-W joints have structurally controlled graphite occurrences, as seen in the Dodangaslanda graphite mine.

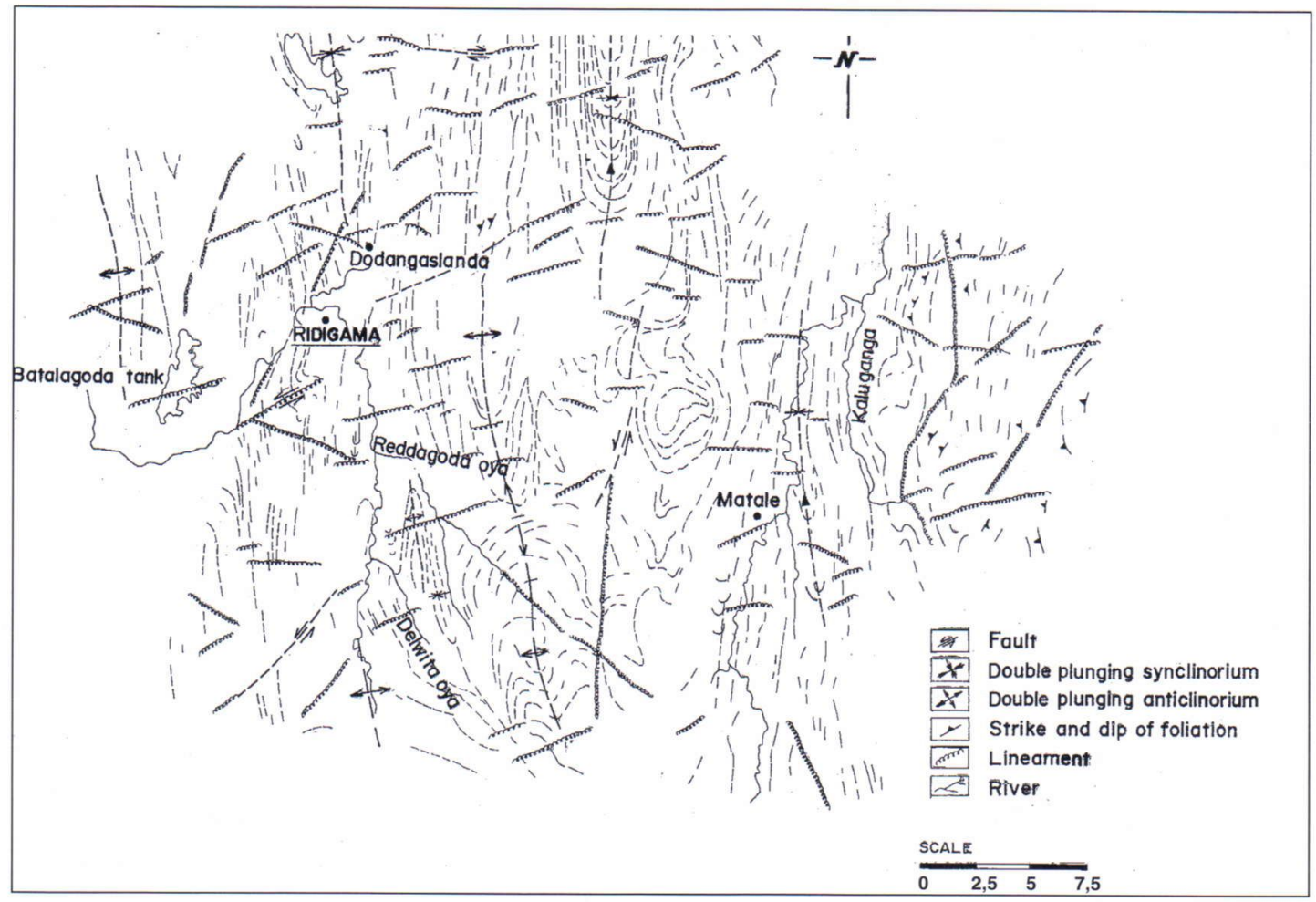

Fig. 6. Areal photographic interpretation of Ridigama area showing the geological structure. 


\section{Wariyapola}

This area (Fig. 1) consists of a single plunging synclinorium and anticlinorium, the structures being quite open, and not as tight as in any of the previous cases. The area falls into the Western Vijayan Complex but the Highland Group is in the near vicinity. No gems have been reported from this area so far.

\section{DISCUSSION}

In the areas investigated, the two major types of gem occurrences observed were as follows :

(a) residual

(b) alluvial

In the foregoing discussion, reference is mainly to the residual and in situ gem deposits as they appear to be controlled by the structure and tectonics.

As in the case of other synclinoria in the Highland/ Southwestern Complex of Sri Lanka, the Bakamuna - Hattota Amuna synclinorium shows thickening of bands at its axial plane (Fig. 4). The precence of marble is an indicative tectonoc feature encompassing a solid state flow towards the axial plane. This is proved bythe occurence in the marble pieces of broken rock of a more competent nature. These rocks may have been present in areas adjacent to the nose of the synclinorium. All rock types can be traced right round the synclinorium along its strike. The dips of foliation planes vary from steep to moderate at the limbs and moderate to shallow at the nose areas. In contrast to most of the other synclinoria in the Highland Complex, the Bakamuna - Hattota Amuna synclinorium displays mobilization of metasedimentary marble at its limbs into intrusive marble at the nose area. The granitic gneisses follow the same pattern and change into pegmatites at its nose areas.

The tectonically intruded marble can be readily distinguished from the metasedimentary marble as the former is very coarse grained $(>4 \mathrm{~cm}$ in diameter). The geological traverses made across the synclinorium axis, at Hattota Amuna region confirmed that corundum is found in association with the tectonically intruded marble. The latter is generally pure and white or light yellow to grey, but impurities of garnet, spinel etc. are very common and the percentage of impurities change considerably from place to place. In situ corundum pits associated with such marble are common at Hattota Amuna especially in the Wallewela area. An in situ corundum vein enveloped by some graphite was found along the axial plane at Wallewela. The fractured and off-gem quality corundum crystals with well-preserved crystal faces, up to $10 \mathrm{~cm}$ long and $6 \mathrm{~cm}$ wide, were common. The corundum occurs about 7-8 $\mathrm{m}$ beneath the ground surface. The extension of the direction of vein being N-S which is the axial plane of the major synclinorium.

Most of the gem deposits along the axial plane e.g. post office area of Hattota Amuna, Wallewela and along the road from 17 to 26 mile posts from Elahera to Hattota Amuna were found in a residual state. In certain localities the gems had well developed crystal faces indicating lack or no transportation. However, well rounded quartz or other rock pieces were also found in most of these pits indicating possible flooding and transportation in the past.

\section{CONCLUSIONS}

In situ and residual corundum of the Hattota Amuna area are associated with tectonically intruded marble which is limited to the axial plane of the large scale Bakamuna - Hattota Amuna synclinorium. In this region, it appears that the size of the geological structure has an effect on the origin and occurrence of gemstones. This is indicated by the Bakamuna Hattota Amuna synclinorium (axial plane length $\mathrm{x}$ wave length: $>35 \mathrm{~km} \mathrm{x}>10 \mathrm{~km}$ ) where there is a wide variety of gemstones including numerous occurrences of corundum; the medium sized Pubbiliya antiform (10-15 km x 3-4 km), $12 \mathrm{~km}$ west of the Hattota Amuna, has only gem quality garnets; finally the smallest synform (5-7 km x 1-3 
$\mathrm{km}$ ) at further $5 \mathrm{~km}$ west of Pubbiliya, has no commercial scale gem deposits.

Examples of deposits controlled by necking zones and pinch and swell structures are few. Such occurrences are seen north of Opanayake, at Hunuwalkanda and this area is also rich in the same varieties of gems as Opanayake.

The NW-SE fault zone at Migasdeniya, SE of Opanayake carries all the gem varieties found around Opanayake. The north cave fault zone at the east of Bogawantalawa area also carries the same gem varieties as found in Bogawantalawa. Both fault zones are quite rich in pegmatite intrusions.

The NW-SE fault zone north of Pubbiliya is not as prominent a gem-bearing area as the other examples. However, granitic pegmatites and small gem quality garnets are common in the rocks along the fault zone.

Each area investigated mainly consists of granulite facies rocks. Marble, quartzite, charnockitic gneiss, hornblende gneiss, granitic gneiss, garnet gneiss, garnet graphite gneiss and sillmanite gneiss are some of the rock types. These rocks can be traced for many kilometers along strike. Usually the rocks are folded into doubly plunging synclinoria/anticlinoria or even simpler synform/antiform structures. The consequent tectonic phases have disturbed, moved or overturned most of these structures.

Subsequent physical denudation processes such as erosion, weathering and landslides have given rise to morphology and structure of a more complex nature. As such, the same rock-typr cannot be traced continuously in most of the places within the gemming regions.

Investigation and the past experiences of miners reveal that gems are not found everywhere even within gemming regions. In situ and residual gem deposits in the areas investigated normally occur in association with the axial planes of synclinoria/ anticlinoria structures, fault zones and lineament zones. Better occurrences of gems were noted within these structures if they are accompanied by the mobilized/anatectic pegmatite or tectonically intruded marble.

High concentrations of rare earth elements and other economically useful elements such as $\mathrm{V}, \mathrm{Rr}$, $\mathrm{Zn}, \mathrm{Cr}$ etc. were observed at a fault zone with more prominent displacement NE of Pubbiliya.

\section{ACKNOWLEDGEMENTS: This work was carried} out with the aid of a grant from the International Development Research Centre, Canada, which in September 1988, approved grants to the Institute of Fundamental Studies and the Laurentian University to jointly pursue the investigation. Grateful thanks are due to Drs J.F. Davies and R.E. Whitehead of the Laurentian University, our counterparts in this project for their invaluable comments, suggestions and for their companionship in the field. Ms. Linda Hayward and Mr. M. Leroux are also thanked for their assistance. Ms. H. Aluwihare kindly drafted the diagrams and Ms. Sharmini Perera typed the manuscript. 


\section{REFERENCES}

Dahanayake K., Liyanage A.N., and Ranasinghe A.P. 1980: Genesis of Seimentary Gem Deposits in Sri Lanka. Sedimentary Geology 25, 105-115.

Dissanayake C.B., Rupasinghe M.S., and Dharmaratne 1992. Fluorine hydrochemistry in a topaz-rich area in Sri Lanka. Zeitschrift der Deutsche Gemmologischer Geselschaft, 41, 111-116.

Gamage S.J.K., Rupasinghe M.S., and Dissanayake C.B. 1992: Application of $\mathrm{Rb}-\mathrm{Sr}$ ratio to gem exploration in the granulite belt of Sri Lanka. Journal of Geochemical Exploration 43, 281-292

Kroner A., Cooray P.G., and Vithanage P.W. 1991: Lithotectonic Subdivision of the Precambrian
Basement in Sri Lanka. In: Kroner, A. (ed.): The Crystalline Crust of Sri Lanka Part I, Summary of Research of the German-Sri Lankan Consortium. Geol. Surv. Dept. Sri Lanka. Prof. Paper 5, 5-21.

Kriegsman L., (1991): Strucutural Geology of the Basement - A preliminary review In: Kroner, A. (ed.): The crystalline crust of Sri Lanka. Part I, Summary of Research of the German-Sri Lankan Consortium. Geol. Surv. Dept. Sri Lanka. Prof. Paper 5, 52-68.

Mendis D.P.J., Rupasinghe M.S., and Dissanayake C.B., 1991. Structural Control of Some of the Residual Gem Deposits Sri Lanka. (Abstract) In: Pagel \& Leroy (eds.): Source, Transport and Deposition of Metals. 